\title{
Pleuroperitoneal leak in a peritoneal dialysis patient
}

\author{
Muhammad Asim, ${ }^{1,2}$ Eiman Mohamed Hamid ${ }^{1}$
}

${ }^{1}$ Department of Medicine, Hamad Medical Corporation, Doha, Qatar

${ }^{2}$ Department of Clinical Medicine, Weil Cornell Medical College in Qatar, Doha, Qatar

\section{Correspondence to} Dr Muhammad Asim, mua2002@qatar-med.cornell. edu

\section{DESCRIPTION}

An abnormal communication between peritoneum and pleural space might exist as a result of congenital or acquired defect in the diaphragmatic muscle fibres/connective tissue. ${ }^{1}$ In the presence of such a communication in a patient on continuous ambulatory peritoneal dialysis (CAPD), any undue increase in intra-abdominal pressure secondary to high dwell volumes, chronic cough or straining can lead to a higher pleuroperitoneal pressure gradient and thus facilitate translocation of dialysate into the pleural space.

A patient with end-stage-renal-disease on CAPD presented with exertional dyspnoea. Physical examination and a chest X-ray (CXR) confirmed left pleural effusion. Aspirated pleural fluid was classified as a transudate based on its alkaline $\mathrm{pH}$, low protein content and low lactic dehydrogenase level. A striking feature of the pleural fluid was its very high glucose concentration as compared with blood glucose. This was due to the presence of dextrose containing dialysate that had translocated from the peritoneal cavity into the pleural space via an anatomical defect in the diaphragm. Isotopic peritoneography (figure 1) using Tc-99 DTPA demonstrated prompt reflux of the tracer in the left pleural space substantiating the presence of a pleuroperitoneal communication.
The peritoneal fluid was drained out, CAPD was discontinued and the patient was switched to haemodialysis. A follow-up CXR 2 weeks later showed complete resolution of pleural effusion. The patient preferred to stay on haemodialysis and therefore reintroduction of $\mathrm{CAPD} /$ intervention for pleuroperitoneal defect was not pursued.

\section{Learning points}

- Pleuroperitoneal leak should always be considered in the differential diagnosis of a pleural effusion developing in a patient on continuous ambulatory peritoneal dialysis.

- Isotopic peritoneography can demonstrate radioisotope tracer refluxing into the pleural space.

- Measurement of pleural fluid glucose is a simple and reliable means for diagnosing pleuroperitoneal leak. ${ }^{2}$

Contributors MA participated in acquisition and formatting of image, critical revision and final approval of the manuscript. EMH participated in acquisition of clinical data, initial draft of the article and final approval of the manuscript.
To cite: Asim M Hamid EM. BMJ Case Rep Published online: [please include Day Month Year] doi:10.1136/bcr-2013200130

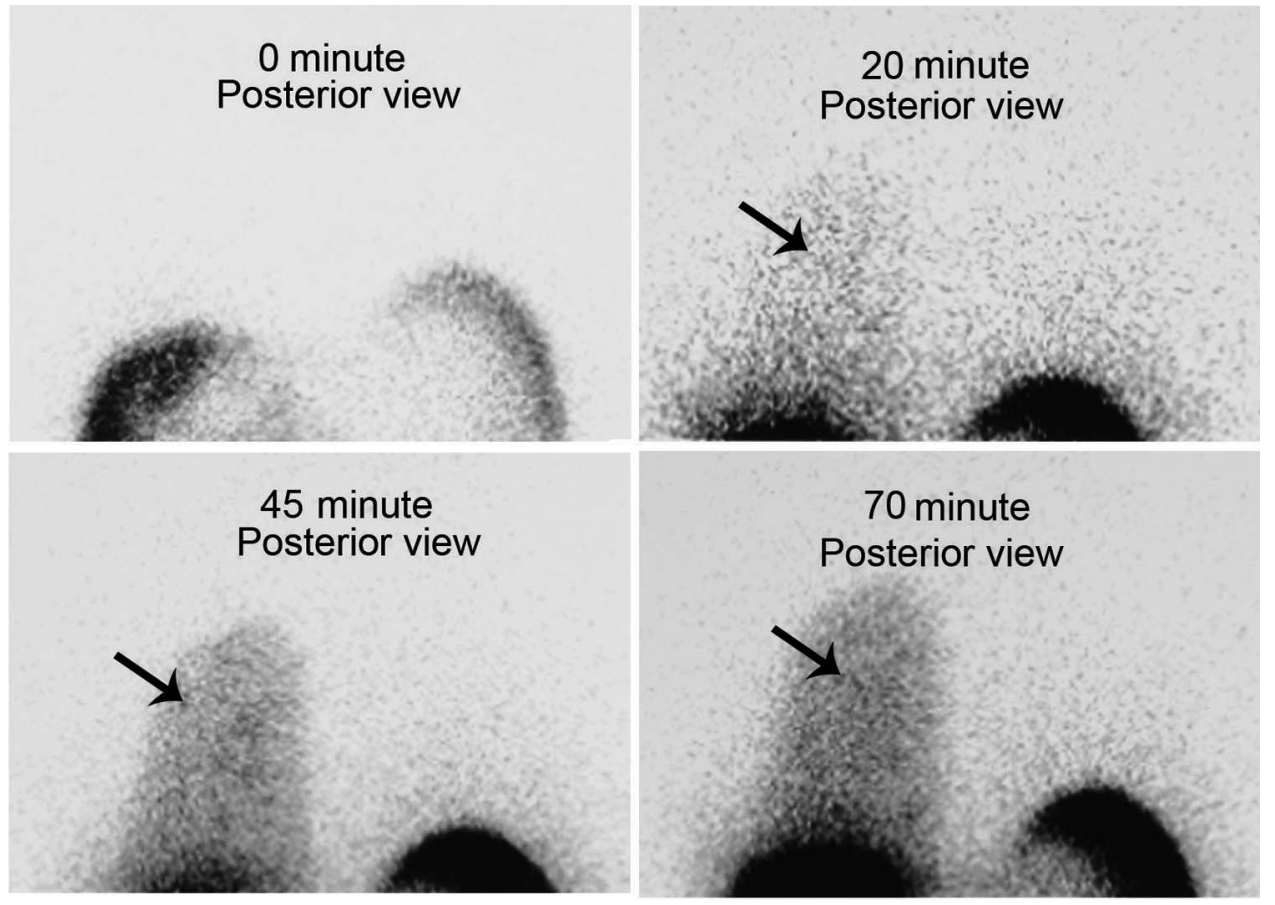

Figure 1 Isotopic peritoneography (posterior views): serial scintigraphic views obtained after instillation of Tc-99 DTPA mixed dialysate into the peritoneal cavity via the peritoneal catheter. Initially, diffuse activity is seen only in the abdominal cavity (0 min frame) but later on, progressive increase in radiotracer activity is demonstrated in left pleural space (black arrows) signifying reflux of tracer material via the pleuroperitoneal communication. 
Competing interests None.

Patient consent Obtained.

Provenance and peer review Not commissioned; externally peer reviewed.

\section{REFERENCES}

1 García Ramón RA, Carrasco M. Hydrothorax in peritoneal dialysis. Perit Dial Int 1998;18:5-10.

2 Chow KM, Szeto CC, Wong TYH, et al. Hydrothorax complicating peritoneal dialysis: diagnostic value of glucose concentration in pleural fluid aspirate. Perit Dial Int 2002;22:525-8.

Copyright 2013 BMJ Publishing Group. All rights reserved. For permission to reuse any of this content visit

http://group.bmj.com/group/rights-licensing/permissions.

BMJ Case Report Fellows may re-use this article for personal use and teaching without any further permission.

Become a Fellow of BMJ Case Reports today and you can:

- Submit as many cases as you like

- Enjoy fast sympathetic peer review and rapid publication of accepted articles

- Access all the published articles

- Re-use any of the published material for personal use and teaching without further permission

For information on Institutional Fellowships contact consortiasales@bmjgroup.com

Visit casereports.bmj.com for more articles like this and to become a Fellow 